\title{
Culture heritage and identity - some cases in Taiwan on the protection of cultural heritage
}

\author{
Rémi Wei-Chou Wang ${ }^{\mathrm{a}}$ * \\ ${ }^{a}$ Dept. of Architecture, National Taipei University of Technology, Taipei, Taiwan remi.wang2@gmail.com
}

KEY WORDS: Cultural heritage, identity, Taiwan

\begin{abstract}
:
The protection of cultural heritage relates to an issue of identity. How a nation or a state tries to face to its history is often revealed on the protection of cultural heritage. Taiwan is as a country with complex history, especially the period after World War II. This article will work on some significant cases, regarded as ideological representation of identity.

This article works on the cultural identity by observing and analyzing different cases of classified Historic Monuments. In different political periods, we see how the government tries to fabricate on the identity issue by working on Historic Monuments preservation. During the presidency of Chiang Kai-shek and his son Chiang Ching-kuo, the classification of Historic Monuments tried to focus on those make by former Chinese migrants. They tried hard to establish and reaffirm the ever existing "fact" of people in Taiwan. Whereas after the late 1980s and 1990s, after Chiang's reign, local conscience has been awaken. Political ambience turned to a new era. This freedom of speech of post-Chiang's reign encourages people to seek on their identity. The complex political situation of Taiwan makes this seeking cultural identity related to the seeking of independence of Taiwan. The respect to the aboriginal people also reoriented to include the preservation of their tribes and villages.
\end{abstract}

\section{QUICK BROWSING TAIWAN'S HISTORY OF TWENTITH CENTURY}

Taiwan is an island considered to be the origin of Austronesian people. This theory is announced by a linguistic Blust in 1985 and an archaeologist Bellewood in 1991. Portuguese were the first European coming to Taiwan, and named it as "Ilha Formosa" around mid-sixteenth century. In the seventeenth century, Dutch East India Company (V.O.C.) invaded Pescadores Island, and fighting with Ming Dynasty and finally agreed to retreat Taiwan, which was not a territory of Ming Dynasty. In 1624, Dutch established a trading post in present Tainan City, in the south of Taiwan, and built Fort Zeelandia. Yet Spaniards built Fort San Salvador in the northern Taiwan. A Sino-Japanese pirate Koxinga resided in Taiwan by expelling Dutch, took it as a base to fight against Qing Dynasty in Mainland. Chinese migrants from Fujian and Guangdong crossed the Taiwan Strait after his surrendering to Qing Dynasty. This begins the Chinese migrants history in Taiwan.

Japan started its modernization (or Europeanization) in the second half of nineteenth century. The First Sino-Japanese war took place in April 1895, Qing Dynasty was defeated and signed the Treaty of Shimonoseki. Taiwan has been ceded to Japan by this Treaty. While Japan colonizes Taiwan from 1895 to 1945 , till the end of World War II. During this fifty years, Taiwan was modernized and industrialized by the colonial government.

After World War II, Japan surrendered. Japan's Government was forced to abandon Taiwan and Penghu. Chinese Government took in charge of Taiwan and sent Chen Yi to manage Taiwan. Then the Nationalist Government lost the civil war against communist army and finally lost Mainland China in 1949. The Nationalist Government, led by Chiang Kai-shek refuged in Taiwan after the civil war. Taiwan become "Republic of China", and Kuomintang stay in power for many years..

Japanese colonial Government approved laws for the protection of heritage of different nature in this island. After World War II, when Chiang Kai-shek and the Nationalist Government come to Taiwan after Mao Zedong and the Communist Party took over the Mainland China in 1949, we observe some interesting phenomena. There were some different ways of dealing with buildings and infrastructures left by Japanese colonial Government. We might be able to conclude in two different ways: destruction, and replacement. For those that have been destroyed, for example, the Nationalist Government destroys systematically Japanese shrine, especially jinja temples. The Government replaces with National Martyrs' Shrines systematically at the same sites. The Japanese colonial government set a series of laws to protect historical monuments and natural resources. The Nationalist government of Chiang Kai-Shek tries to protect historical monuments, however, the monuments to be protected is very selective.

\section{THE FIRST LIST OF PRESERVATION}

The first version of the Cultural Heritage Preservation Act had been approved in May 1982. Before the approval of this Act, all Historic Monuments were protected by the Ancient Artifact Preservation Act (approved in 1931). The first list of Historic Monuments classified Monuments in three grades, by their historic or cultural importance, and also by their aesthetic quality. It is named "Historic Monuments of Taiwan and Fujian Provinces. The First Grade lists 24 Historic Monuments (Ministry of Interior is in charge), the Second Grade lists 50 (Provincial Government is in charge), and the Third Grade includes 223 monuments (local governments are in charge). The 
quantity of each grade shows their importance, also by the different level of governments.

They are also classified according to their nature. The different categories are listed by Article 2 of Implementation Rules for the Cultural Heritage Preservation Act. They are shrine, temple, mansion, castle, fortress, government office, train station, school, stele, church, tomb, dike, lighthouse, bridge and industrial facilities, etc..

\subsection{The List of Historic Monuments of Taiwan and Fujian Provinces}

The List of First Grade Monuments contains 24 monuments, most of them are classified from 1983 to 1988, after the very first Cultural Heritage Preservation Act approved in 1982. This list, revealed the said ideology of government at that time, is significant to the mentality and ideology of the Government in 1980s. Besides monuments related to Chinese people of Ming and Qing Dynasties, five archeological sites related to the aboriginal culture are also classified on the List of First Grade.

\begin{tabular}{|l|l|l|}
\hline Name of the Historic Monument & categories & $\begin{array}{l}\text { Year of } \\
\text { classifica } \\
\text { tion }\end{array}$ \\
\hline $\begin{array}{l}\text { Taipei Citadel and its gates (East, South, South } \\
\text { minor, North) }\end{array}$ & Castle & 1998 \\
\hline Yuanshan Historic Site & $\begin{array}{l}\text { Historic } \\
\text { site }\end{array}$ & 1988 \\
\hline Fongshan Old Citadel & Castle & 1985 \\
\hline Changhua Confusius Temple & Shrine & 1973 \\
\hline Lukang Longshan Temple & Temple & 1973 \\
\hline Pantounkua trail & $\begin{array}{l}\text { Historic } \\
\text { site }\end{array}$ & 1987 \\
\hline $\begin{array}{l}\text { Memorial arche dedicated to the Mother of Chiu } \\
\text { Liang-kong }\end{array}$ & $\begin{array}{l}\text { Memorial } \\
\text { arche }\end{array}$ & 1985 \\
\hline Fort San Domingo & Castle & 1983 \\
\hline Tapenkeng archeological site & $\begin{array}{l}\text { Historic } \\
\text { site }\end{array}$ & 1992 \\
\hline Ching-Kuang-Fu Mansion & Mansion & 1983 \\
\hline Wang De-lu Tomb & Tomb & 1983 \\
\hline Beinan archeological site & $\begin{array}{l}\text { Historic } \\
\text { site }\end{array}$ & 1988 \\
\hline Pa-hsien Grotto & $\begin{array}{l}\text { Historic } \\
\text { site }\end{array}$ & 1988 \\
\hline Penghu Matsu Temple & Temple & 1983 \\
\hline Siyu West Fort & Fortress & 1983 \\
\hline Siyu East Fort & Fortress & 1991 \\
\hline Uhrshawan Battery at Keelung & Fortress & 1983 \\
\hline Tainan Confucius Temple & Shrine & 1983 \\
\hline Sacrificial Rites Martial Temple & Shrine & 1983 \\
\hline Temple of Five Concubines & Shrine & 1983 \\
\hline Relic of Fort Zeelandia & Castle & 1983 \\
\hline Fort Provintia & $\begin{array}{l}\text { Governme } \\
\text { nt } \\
\text { building }\end{array}$ & 1983 \\
\hline Uhrkuenshen Battery (Eternal Golden Castle) & Fortress & 1983 \\
\hline Sacrificial Rites Grand Matsu Temple & Shrine & 1985 \\
\hline
\end{tabular}

Table 1. List of First Grade Historic Monuments

By browsing the List of the most important Historic Monuments, we find a phenomenon. The Nationalist government focuses on the protection of monuments built by Chinese migrants. Koxinga Shrine, a temple dedicated to Koxinga, i.e. Cheng Cheng-kong. Koxinga is a former pirate regarded as a successor of Ming Dynasty, who fought against Qing Dynasty. He crossed Taiwan Strait, swept Dutch away in 1661, and stationed at Anping (a quarter of Tainan City today). We can easily understand why Koxinga Shrine was one of the highlighted monuments to protect. Koxinga is a successor of Ming Dynasty fighting against Qing Dynasty (which is Manchu) but finally surrendered to the Qing Dynasty. Manchu are totally different from Han people, and have always been considered to be barbarians), who liberated Taiwan from Dutch colonization, then finally stationed in Taiwan (an analogy to Chiang Kaishek?). This is the reason why Koxinga Shrine is classified. Except for Koxinga Shrine, there're very many other buildings classified as historical monuments to be protected, such as Confucius Temple and Longshan Temple at Lukang, Official God of War Temple (Sacrificial Rites Martial Temple) and Grand Matsu Temple at Tainan, etc. They represent the Chinese immigration history, and their culture attached to the Mainland China. And, besides their history, they're of great esthetic quality on space and construction.

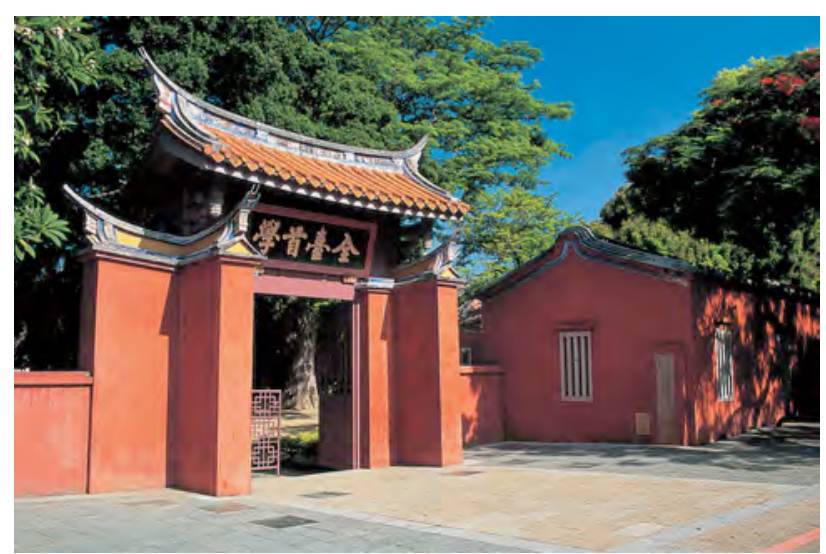

Fig. 1 Confucius Shrine in Tainan

(http://www.atgapp.com/scence/TainanConfuciusTemple.php)

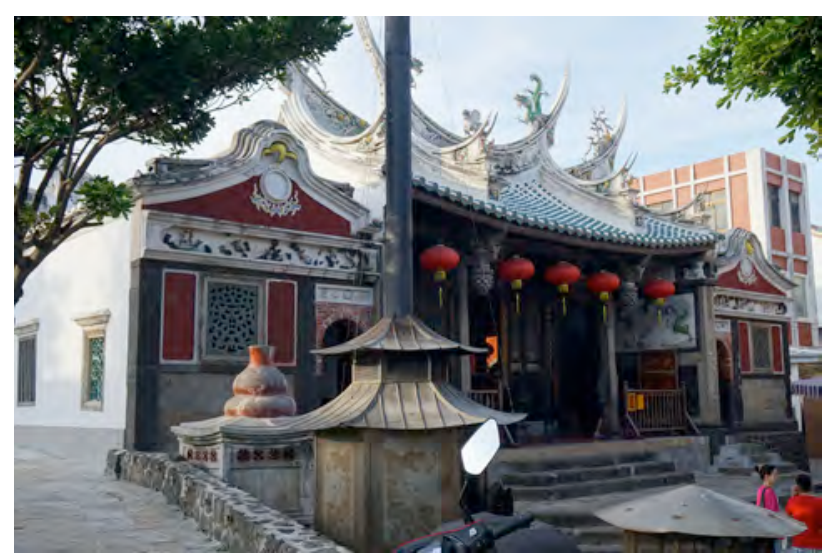

Fig. 2 Penghu Matsu Temple

\section{CRITERIA OF CLASSIFICATION OF HISTORIC MONUMENTS}

The protection of cultural heritage under the Chiang Kai-shek and Chiang Ching-kuo reign carries the ideology and the point of view of the "Great China ». For Chiang Kai-shek reclaims himself as the official power inheriting the Republic of China, founded by Sun Yat-sen. He, and his Kuomintang (KMT, the Nationalist Party) comrades reside in Taiwan after losing civil war against Mao and his Communist Party. They took their residing in Taiwan as a temporary situation, and prepare moving back to China. The international geopolitical ambiance did offer some opportunities to them. This made Kuomintang's ruling Taiwan with the point of view of ruling China.

Taiwan contains different history from the one of China, especially the «History» made of different successors of dynasties. Though the aboriginal people in Taiwan are considered to be the origin of Austronesian people, with at least 
four thousand years of history in Taiwan, they didn't build up huge monuments of great scale. The Chinese immigrants after Koxinga brought their cultural forms and their monuments. They built their temples, shrines and houses mostly inherited from southern Fujian (Min-nan). Through several centuries of history of Chinese migration to Taiwan, and the history they made of by fighting against aboriginal people to gain the land, Chinese people did mark their footprint in Taiwan. The fluctuation of Chinese population versus aboriginal population and their land on this island Formosa, reveals the very history of Taiwan. The construction of different people and different tribes also witness their existence in the timeline. Even so, the classification of historic monument still shows their interest on Chinese heritage. We try to decode by analyzing the classified Historic Monuments.

According to the old criteria (more an understanding) by the members of superior committee of heritage of Ministry of Interior (formerly in charge of Cultural Heritage), or those of local committee, the "at least one hundred year" seemed to be one of the major criteria for the classification. But somehow, it was not mentioned in the text of the first version of Act for the Protection of Cultural Heritage. It seemed to be reasonable for experts to classify with the classical criteria on the "age" of a classified monument. This is a criterion to exclude the classification of those buildings built during the Japanese Rule (from 1895 to 1945), which are quite important in their scale and in their architecture. If we revise the list over again, in the very first list of 24 First Grade Historic Monuments, there is no one that is classified of this period. In fact, there are some exception, the ages are more counted from their founding origin The Gates of Taipei Citadel are actually restored (more rebuilt than restored) in 1966 (Except for the North Gate). The actual Longshan Temple of Taipei is rebuilt in 1920 during the Japanese Rule, though it is declaimed to be the built around Eighteenth Century. On the contrary, there's no doubt for monuments or buildings constructed by Japanese colonial government.

With the phenomenon, we might conclude that the Government did have some vision on cultural heritage preservation, for serving a hidden political intension behind. It is to discover what, consciously and sub-consciously, made all these decision of classification.

\section{THE NATIONALIST GOVERNMENT AFFIRMING ITS SOVEREIGNTY}

The Nationalist Government led by Chiang Kai-shek encountered some difficult situations while moving to Taiwan, including exterior and interior ones. He was against Communist China by Mao, to stay as "Free China", supported by the United States. At the same time, he had to deal with Taiwanese society formerly colonized by Japan during 50 years. The country has been modernized during the Japanese Rule. Whereas the Nationalist Government went through very long wars against the Japanese and Communist. Chiang and his government faced the riot against his power, the 228 Affair was just the prelude. The Nationalist government and its army massacre elites in Taiwan. And then, it comes the White Terror afterward. Many were arrested or executed by being suspected to be spies.

Later on, while Mao and his fellows inaugurated Cultural Revolution in Mainland China in 1960s, Chiang launched Cultural Renaissance in Taiwan. In such historic context, to affirm his sovereignty, Chiang Kai-shek took some necessary steps. To link the relation with Mainland China and Taiwan, Chiang tried to convince people politically and culturally. To convince politically for those coming with Nationalist Government to stay in Taiwan, embracing hope to conquer China and going home. To convince culturally, especially for Taiwan's people being colonized for fifty years. To reinstall the Chinese cultural influence to Taiwan, and for giving people some comfort to their nostalgia, all cultural traces by the migrant-ancestors should be regarded to be the primordial one to be protected.

Chiang Kai-shek died in 1975, shortly succeeded by Yen Chiakan, the Vice President. The son of Chiang Kai-shek, Chiang Ching-kuo inherited the presidency from 1978 to 1988. The first version of Cultural Heritage Preservation Act has been approved during his presidency.

Local Cultural Movement has been held in 1970s. Maybe this is the influence of Cultural Renaissance held by Chiang Kai-shek. The nostalgia behind the Local Cultural Movement put the society in a retrospective ambience. People in Taiwan, under the sorrow of withdrawing from the United Nations and the pressure of White Terror, sought a way out of their emotion. Fighting back to Mainland China seemed to be farther and farther. People originated from China and moving to Taiwan with Nationalist Government despaired, feeling abandoned by the international community. They had some collective home sick symptom. Nevertheless, they seemed to agree and accept the discourse made by the Nationalist Government.

The whole society and political power at that time was strongly Sino-centered, even Han-chauvinist. The hatred against Japan of Nationalist Government led no possibility to recognize the existence of fifty years of colonization in Taiwan. There exists some strong discrimination towards Aboriginal people and their culture. Though Cultural Heritage Preservation Act is approved, but the practice of preservation in different level of governments was still focused on the Chinese culture.

\section{CONCLUSION}

This historic course from the end of World War II to the end of Chiang Ching-kuo's reign reveals strongly a case of classification of Historic Monument and cultural identity of the society. The Nationalist Government under the name of Republic of China leads Taiwan go through this period with complex history of international politics. Chiang Kai-shek and his son Chiang Ching-kuo tried hard to work on the identity issue, to confront Red China and to affirm their sovereignty.

We find that the Government classified mostly monuments or buildings built by Chinese migrants to witness the existence of Chinese culture, and tried to reaffirm the connection to the Mainland China. The Government built the cultural identity by fabricating cultural heritage. The aboriginal cultural heritage had been somehow ignored, and the monuments built during the Japanese Rule is also expelled purposely.

Under the pressure of White Terror, people in Taiwan didn't question much about the history of Taiwan. They are taught to be official inherit of the Great China. This cultural identity made by the Nationalist Government didn't represent the complexity of the people and their histories (plural, because of different people of divers origins and ethnics in Taiwan). This identity fabricated are far from the true aspect of Taiwan. 
This paper tried to work on the identity issue, through the observation of political and social context. The result of the preservation of historic monuments becomes meaningful. This is not the result of series of single event of classification, but a policy to fabricate history and identity at that time. Things change after 1990s. It's another story.

\section{REFERENCES}

Ashworth G. J. \& GRAHAM B., series editor, 2005, Sense of Place: Sense of Time (Heritage Culture and Identity), Ashgate Publishing Ltd.

Bercé, F., 2000, Des monuments historiques au patrimoine, du XVIII siècle à nos jours, ou "Les égarements du cours et de l'esprit », éditions Flammarion, Paris.

Cattedra R., Garret P., Miller C., Volait M., 2010a, Patrimoine en situation, in Constructions et usages en différents contextes urbains. Exemples marocains, libanais, égyptien et suisse, Presse de l'IFPO.

Cattedra R., La «fabrication» $\mathrm{du}$ patrimoine comme construction de l'identité urbaine. 2010, L'exemple de Casablanca, in Constructions et usages en différents contextes urbains. Exemples marocains, libanais, égyptien et suisse, Presse de l'IFPO.

Fournier L. S., Crozat D., Berne-Boissard C., Chastagner C., sous la direction de, 2012, Patrimoine et désir d'identité, Editions L'Harmattan.

Graham B., \& Howard P., 2008, The Ashgate Research Companion to Heritage and Identity, Ashgate Publishing Ltd.

Hagen, J., 2006, Preservation, Tourism and Nationalism: The Jewel of the German Past, The Ashgate Publishing Ltd.

Heinich, N., 2009. La fabrique du patrimoine - de la cathédrale à la petite cuillère, Editions de la Maison des sciences de l'homme.

Hsia C.-J., 1998. Historic Preservation in Taiwan: A Critical Review, in Journal of Building and Planning of National Taiwan University 9, pp.01-09.

Moore, N., Whelan, Y., 2007. Heritage, Memory and the Politics of Identity: New Perspectives on the Cultural Landscape, The Ashgate Publishing Ltd.

Poulot, D., 1997. Musée, nation, patrimoine, 1789-1815, éditions Gallimard, Paris.

Wang, R. W.-C., 2013. Conservation, a reflection of Ideology a case study on Lou Yi-Juinn and his architecture, in 2013 Xi' an International Conference of Modern Architecture Heritage Conservation - « Other MoMo, Other Heritage », pp.

Waterson E., Watson S., edited by, 2010, Culture, Heritage and Representation (Heritage, Culture and Identity), Perspective on Visuality and the Past, Ashgate Publishing Ltd.

Ye, N.-G., 1989. 古蹟保存論述之形成 - 光復後台灣古蹟保 存運動, thesis of Master Degree, Institute of Civil Engineering, National Taiwan University.
Republic of China, Cultural Heritage Preservation Act, https://zh.wikipedia.org/wiki/\%E6\%96\%87\%E5\%8C\%96\%E8 \%B3\%87\%E7\%94\%A2\%E4\%BF\%9D\%E5\%AD\%98\%E6\%B3 $\% 95$ (June 2015). 